and mystical performances had been gone through by all the natives, the old chief produced the "rain-stone," which had been carefully kept wrapped-up in leaves and a piece of rag, and showed it to Mr. Slee, but would not let him to touch it. He then buried it in the-sand.

On one of the creeks near the diggings are some marks of a high flood, which the natives said took place after they had performed the above mentioned ceremony over an unusually large rain-stone.

\title{
On the Brain of Grey's Whale (Kogia Greyi.)
}

By William A. Haswell, M.A., B.Sc.

[Plate XXI.]

The acquisition recently by the Australian Museum of a fresh specimen of Grey's Whale has afforded me the opportunity of examining the brain of this rare Cetacean. For comparison I have the brain of only one other species, viz., that of the species of Delphinus (D. Fosteri) common on the New South Wales Coast.

The total length of the Kogia was nine feet six inches, which may be regarded as about the average length of these small Cetaceans. The length of the encephalon is $6 \frac{1}{2}$ inches, of which $4 \frac{1}{4}$ inches are taken up by the cerebral hemispheres; the weight of the whole brain with the membranes removed is about 16oz. In the medulla the olivary bodies are very large, though scarcely so prominent as in Delphinus. The cerebellum is relatively much smaller than in Delphinus; the greatest breadth is about four inches, the mesial lobe is smaller in proportion, and the lateral lobes are nearly symmetrical. The pons is not prominent, its breadth is about an inch, and its anteroposterior extent less than three-tenths of an inch. The anteroposterior extent of the nates is greater than that of the testes, but the latter are much the more prominent; they are separated on either side by a well-marked groove which makes an angle of about $60^{\circ}$ with the mesial longitudinal axis. 
The greatest breadth of the cerebrum (six inches) is considerably greater than its length ( $4 \frac{1}{4}$ inches), and in fact exceeds the total lenyth of the encephalon. Its greatest vertical thickness is two inches. It is narrower in front than in Delphinus, and the general shape is more nearly triangular. The convolutions of the upper surface are, as in most Cetacea, highly complex, and arranged in parallel longitudinal folds, but these are better defined than in Delphinus, and their dividing sulci are remarkably deep. There is an inner narrow longitudinal fold thinning off anteriorly; and external to it three wider ones; the two inner of these are cut off from one another throughout the greater length of the brain by a deep sulcus, the second and the third are not so deeply divided and are united about the middle of their length by an annectent gyrus which is much broader on the right side than on the left. A fifth fold is traceable, but not so well defined. On the inner surface of the hemispheres the convolutions are arranged in two tiers, the upper very complex with numerous transverse gyri, the lower simpler; these are separated by a very deep longitudinal sulcus. The convolutions of the orbital and ethmoidal surfaces are chiefly longitudinal. The most remarkable peculiarity of this region, and perhaps of the whole brain, is the great depth of the ectorhinal sulcus, a feature marking off the present form very strongly from Delphinus. The temporo-sphenoidal lobe is marked by numerous short, irregularly arranged convolutions. The apex of the lobe, consisting of two convolutions placed nearly longitudinally, is sharply divided off from the rest by a deep sulcus. The convolutions of the tentorial surface follow a radiating arrangement.

The corpus callosum is an inch and three-eighths in anteroposterior extent. It is thin towards the middle and dilated at either end, more particularly in front where it forms a prominent thickening; in transverse section it does not appear uniformly curved, but bent at a very obtuse angle a little behind the middle of its length. The lateral ventricles are of very great breath (more than an inch.) The optic thalami are of large extent and cover the greater part of the floor of the ventricles. The anterior cornua of the lateral ventricles do not pass forwards beyond the 
anterior extremity of the corpus callosum ; the posterior cornua are rudimentary. The hippocampus major is well-defined and ends in a prominent pes; the hippocampus minor is comparatively low and inconspicuous.

Explanation of Plate xxi.

Fig. 1.-Upper view of the brain.

, 2.-Lower view of one half of the brain.

, 3.- Mesial longitudinal section.

On a New Genus of Fishes from Port Jackson. By William Macleay, F.L.S. Plate xxiI.

The Fish here described was captured in a seine net at Watson's Bay by a fisherman, last Friday morning, was taken by Mr. Mulhall, Sub-Inspector of Fisheries, to Dr. Cox, and was by him presented to the Australian Museum. Finding it to be something perfectly new, I lost no time in transferring to paper as accurate a description of it as was possible under the circumstances, for unfortunately the taxidermist of the Institution had already skinned the fish, and thrown away the body. I have had therefore no means of ascertaining the size or shape of the air-bladder, or the number of pyloric appendages, and my measurement of the height of the body of the Fish as compared with its length, has been also to some degree a matter of guess work. For the genus I propose the name of Psilocranium from its bald head, and for the species that of the learned President of the Commissioners of Fisheries.

\section{Genus Psilocranium.}

Of elongate form, scarcely if at all laterally compressed. One dorsal fin, the soft portion much larger than the anal fin. Caudal fin forked. The lower rays of the pectoral fins simple. Teeth in a viliform band in both jaws. Præorbital and præoperculum entire. Scales large, thin, cycloid. Head naked, except on the operculum which is clothed with small non-imbricate scales embedded in the skin. Branchiostegals five, the inner one very small. 


\section{$2 \mathrm{BHL}$ Biodiversity Heritage Library}

Haswell, W A. 1884. "On the brain of Grey's whale (Kogia Greyi)." Proceedings of the Linnean Society of New South Wales 8, 437-439. https://doi.org/10.5962/bhl.part.28672.

View This Item Online: https://www.biodiversitylibrary.org/item/30993

DOI: https://doi.org/10.5962/bhl.part.28672

Permalink: https://www.biodiversitylibrary.org/partpdf/28672

\section{Holding Institution}

MBLWHOI Library

\section{Sponsored by}

MBLWHOI Library

\section{Copyright \& Reuse}

Copyright Status: NOT_IN_COPYRIGHT

This document was created from content at the Biodiversity Heritage Library, the world's largest open access digital library for biodiversity literature and archives. Visit BHL at https://www.biodiversitylibrary.org. 